\title{
PENGARUH PENAMBAHAN GENTAMISIN DAN MINYAK ATSIRI JERUK MANIS TERHADAP PERSENTASE HIDUP SPERMATOZOA PADA PENGENCER SEMEN BEKU SAPI SIMMENTAL
}

\section{The Effect of Additional Gentamicin and Sweet Orange Essential Oil on The Life Percentage of Spermatozoa In Simmental Frozen Semen Extender}

\author{
Sukma Aditya Sitepu ${ }^{1}$ dan Julia Marisa ${ }^{1}$ \\ ${ }^{1}$ Fakultas Sains dan Teknologi, Universitas Pembangunan Panca Budi \\ Email: sukmaaditya@dosen.pancabudi.ac.id
}

\begin{abstract}
ABSTRAK
Penelitian ini bertujuan untuk mengetahui nilai persentase spermatozoa hidup pada semen beku sapi Simmental dengan menambahkan gentamisin dan minyak atsiri jeruk manis pada bahan pengencer tris kuning telur. Bahan yang digunakan dalam penelitian ini adalah semen segar sapi Simmental, pengencer tris kuning telur dan minyak atsiri jeruk manis. Pengencer tris kuning telur dengan menggunakan 3,32 g Tris (hidroksimetilaminometana); 1,86 g asam sitrat; 1,37 g fruktosa; 6 $\mathrm{ml}$ gliserol; $20 \mathrm{ml}$ kuning telur; dan $100 \mathrm{ml}$ aquades. Metode penelitian yang digunakan dalam penelitian ini adalah Rancangan Acak Lengkap dengan 5 perlakuan dan 5 ulangan. Perlakuan yang diberikan adalah penambahan minyak atsiri jeruk manis 0\% (P0); 0,25\% (P1); 0,5\% (P2); 0,75\% (P3) dan 1\% (P4). Hasil penelitian menunjukkan bahwa semakin banyak penambahan minyak atsiri jeruk manis, persentase hidup spermatozoa pada semen beku Sapi Simmental akan terus meningkat. Hasil terbaik ditunjukkan pada penambahan 1\% (P4) minyak atsiri jeruk manis dengan persentase hidup spermatozoa sebesar 88\% (pra pembekuan) dan 75\% (pasca pembekuan).
\end{abstract}

Kata kunci: Jeruk Manis, Minyak Atsiri, Sapi Simmental, Semen Beku, Spermatozoa Hidup

\section{ABSTRACT}

This study aimed to determine the life percentage of spermatozoa in Simmental bull frozen semen by adding gentamicin and sweet orange essential oil to tris yolk extender. The ingredients used in this study were Simmental bull fresh semen, tris yolk extender, and sweet orange essential oil. Tris yolk extender using: $3.32 \mathrm{~g}$ Tris (hydroxymethyl aminomethane), $1.86 \mathrm{~g}$ citric acid, $1.37 \mathrm{~g}$ fructose, $6 \mathrm{ml}$ glycerol, 20 $\mathrm{ml}$ egg yolk, $100 \mathrm{ml}$ aqua dest $(100 \mathrm{ml})$. The research method used in this study was a Complete Randomized Design with five treatments and five replications. The treatments given were the addition of sweet orange essential oil 0\% (P0), 0.25\% (P1), 0.5\% (P2), 0.75\% (P3) and 1\% (P4). The results showed that the more addition of sweet orange essential oil, the life percentage of spermatozoa in Simmental bull frozen semen would continue to increase. The best results showed in the addition of 1\% (P4) sweet orange essential oil that the life percentage of spermatozoa was equal to 88\% (before freezing) and 75\% (after freezing)

Keywords: Sweet Orange, Essential Oil, Simmental Bull, Frozen Semen, Live Spermatozoa

\section{PENDAHULUAN}

Usaha ternak sapi potong di Indonesia saat ini belum dapat memenuhi kebutuhan daging dalam negeri, sehingga pemerintah harus melakukan import dari negara lain baik dalam bentuk daging beku maupun sapi bakalan. Kebijakan import kurang tepat jika dilakukan secara terus menerus karena akan merugikan sektor peternakan nasional sehingga perlu dipikirkan bagaimana cara meningkatkan kualitas dan kuantitas produk ternak sapi potong lokal di dalam negeri dengan 
cara meningkatkan mutu genetik ternak potong. Usaha lain yang dapat dilakukan adalah membantu permodalan bagi peternak, pengendalian penyakit reproduksi dan kesehatan ternak, pengembangan pakan serta mengembangkan mutu bibit ternak sapi potong.

Penggunaan bibit berkualitas baik akan meningkatkan pendapatan usaha ternak (Marisa \& Sitepu, 2020). Usaha meningkatkan mutu genetik ternak sapi potong lokal dapat dilakukan dengan memanfaatkan teknologi reproduksi, salah satunya seperti Inseminasi Buatan. Keberhasilan Insemiansi Buatan ditentukan oleh kualitas semen cair yang digunakan Proses produksi dan pemilihan bahan pengencer semen beku sangat kompleks dan diperlukan penanganan yang tepat sehingga semen beku yang dihasilkan memiliki kualitas yang bagus.

Bahan pengencer merupakan salah satu faktor yang menentukan kualitas semen beku. Pengencer tris kuning telur sering digunakan pada proses preservasi dan kriopreservasi semen berbagai jenis hewan dan ternak. Tris hidroxymethil aminomethan (C4H11NO3) berfungsi sebagai buffer untuk semen (Rizal \& Herdis, 2008). Harga bahan pengencer tris kuning telur jauh lebih murah jika dibandingakan dengan bahan pengencer komersil siap pakai seperti andromed (Salmah, 2014). Penambahan bahan antibakteri pada pengencer tris kuning telur penting dilakukan untuk mencegah kerusakan pada semen beku yang disebabkan oleh bakteri.

Kontaminasi bakteri yang terdapat di dalam semen beku Sapi Simental dapat berasal dari saluran reproduksi, lingkungan, penanganan selama proses pengenceran semen dan lingkungan dan bahan pengencer terutama kuning telur (Toelihere, 1993). Kuning telur sangat rentan terhadap serangan bakteri seperti salmonela dan staphylococcus sehingga akan berpengaruh terhadap ketahanan semen yang menggunakan kuning telur sebagai bahan pengencer (Yuwanta, 2010). Usaha yang dapat dilakukan untuk mengurangi populasi bakteri di dalam semen beku adalah menambahkan antibiotik di dalam bahan pengencer.

Bakteri yang terdapat di dalam semen beku Sapi Simmental dapat menurunkan persentase spermatozoa hidup. Semakin banyak sperma yang hidup maka semakin tinggi keberhasilan fertilitas. Gentamisin aktif terhadap bakteri terutama pada bakteri gram negatif dan positif (Nattadiputra \& Munaf, 2009). Namun penambahan gentamisin masih kurang optimal untuk menghambat pertumbuhan bakteri dalam semen beku.

Minyak atsiri jeruk manis mengandung limonene dan linalool bersifat toksik pada bakteri (Fisher \& Phillips, 2006). Penelitian penggunaan kombinasi penisilin dan minyak atsiri jeruk manis dapat meningkatkan kualitas semen Sapi Simmental (Sitepu \& Marisa, 2019). Pada penelitian ini dilakukan perlakuan kombinasi gentamisin dan minyak atsiri kulit jeruk manis yang diharapkan dapat lebih baik dalam menghambat pertumbuhan bakteri dan meningkatkan presentase spermatozoa hidup pada semen beku Sapi Simmental.

\section{METODE}

Metode penelitian yang digunakan dalam penelitian ini adalah Rancangan Acak Lengkap dengan 5 perlakuan dan 5 ulangan. Materi penelitian adalah semen Sapi Simmental yang telah ditambahkan bahan pengencer tris kuning telur, gentamisin dan berbagai level minyak atsiri jeruk manis. Penambahan gentamisin pada bahan pengencer sebanyak $500 \mu \mathrm{g} / \mathrm{ml}$ (Hasan et al., 2000) dengan perlakuan yang diberikan adalah sebagai berikut:

$\mathrm{P}_{0}=$ Gentamisin $500 \mu \mathrm{g} / \mathrm{ml}+$ Minyak Atsiri Jeruk Manis 0\%

$\mathrm{P}_{1}=$ Gentamisin $500 \mu \mathrm{g} / \mathrm{ml}+$ Minyak Atsiri Jeruk Manis 0,25\%

$\mathrm{P}_{2}=$ Gentamisin $500 \mu \mathrm{g} / \mathrm{ml}+$ Minyak Atsiri Jeruk Manis 0,5\%

$\mathrm{P}_{3}=$ Gentamisin $500 \mu \mathrm{g} / \mathrm{ml}+$ Minyak Atsiri Jeruk Manis 0,75\%

$\mathrm{P}_{4}=$ Gentamisin $500 \mu \mathrm{g} / \mathrm{ml}+$ Minyak Atsiri Jeruk Manis 1\% 
Pengamatan yang dilakukan sebelum dan setelah semen dibekukan adalah persentase spermatozoa hidup. Semen beku setelah thawing dievaluasi dengan menggunakan pewarnaan eosin. Spermatozoa yang hidup ditandai oleh kepala yang tidak menyerap zat warna, sedangkan yang mati ditandai oleh kepala yang berwarna merah. Evaluasi dilakukan pada minimal 200 spermatozoa diamati dengan menggunakan mikroskop cahaya pembesaran 400 kali. Persentase spermatozoa hidup dihitung berdasarkan rumus :

$$
\% \text { Spermatozoa hidup }=\frac{\text { jumlah spermatozoa yang tidak menyerap warna }}{\text { total spermatozoa yang dihitung }} \times 100 \%
$$

\section{HASIL DAN PEMBAHASAN}

Hasil penelitian uji spermatozoa hidup spermatozoa pada Sapi Simmental sesudah pembekuan semen menunjukkan bahwa nilai presentase terendah adalah tanpa perlakuan $\left(\mathrm{P}_{0}\right)$ yaitu 58\% sedangkan yang tertinggi adalah dengan penambahan $1 \%$ minyak atsiri jeruk manis $\left(\mathrm{P}_{4}\right)$ dengan nilai persentase sebesar $75 \%$. Dari data yang diperoleh dapat dilihat bahwa penambahan minyak atsiri jeruk manis meningkatkan nilai presentase spermatozoa hidup pada spermatozoa Sapi Simmental sesudah pembekuan semen. Semakin tinggi level pemberian minyak atsiri jeruk manis akan semakin meningkatkan nilai presentase spermatozoa hidup spermatozoa.

Nilai presentase spermatozoa hidup spermatozoa Sapi Simmental sesudah pembekuan semen lebih rendah jika dibandingkan dengan sebelum pembekuan semen. Hal ini menunjukkan adanya penurunan kualitas semen selama proses pembekuan. Penurunan nilai presentase spermatozoa hidup spermatozoa Sapi Simmental tertinggi ditunjukkan pada perlakuan tanpa penambahan minyak atsiri jeruk manis $\left(\mathrm{P}_{0}\right)$ yaitu sebesar $18 \%$ sedangkan terendah ditunjukkan pada perlakuan penambahan minyak atsiri jeruk manis sebanyak 1\% (P4) yaitu sebesar 13\%.

Tabel 1. Presentase spermatozoa hidup pada semen sapi Simmental sebelum dan setelah pembekuan

\begin{tabular}{cccc}
\hline & & \multicolumn{2}{c}{ Pengamatan } \\
\cline { 3 - 4 } Parameter & Perlakuan & Sebelum Pembekuan & Setelah Pembekuan \\
\hline \multirow{2}{*}{ \% Spermatozoa } & $\mathrm{P}_{0}$ & $76 \pm 2,42$ & $58 \pm 2,50$ \\
Hidup & $\mathrm{P}_{1}$ & $82 \pm 2,78$ & $65 \pm 2,72$ \\
& $\mathrm{P}_{2}$ & $83 \pm 2,50$ & $67 \pm 2,50$ \\
& $\mathrm{P}_{3}$ & $86 \pm 2,72$ & $71 \pm 2,65$ \\
& $\mathrm{P}_{4}$ & $88 \pm 0,77$ & $75 \pm 2,50$ \\
\hline
\end{tabular}

Keterangan: Superskrip yang berbeda pada kolom menunjukkan perbedaan yang sangat nyata $(P<0,01)$

Nilai presentase spermatozoa hidup spermatozoa Sapi Simmental sesudah pembekuan semen lebih rendah jika dibandingkan dengan sebelum pembekuan semen. Hal ini menunjukkan adanya penurunan kualitas semen selama proses pembekuan. Penurunan nilai presentase spermatozoa hidup spermatozoa Sapi Simmental tertinggi ditunjukkan pada perlakuan tanpa penambahan minyak atsiri jeruk manis $\left(\mathrm{P}_{0}\right)$ yaitu sebesar $18 \%$ sedangkan terendah ditunjukkan pada perlakuan penambahan minyak atsiri jeruk manis sebanyak 1\% (P4) yaitu sebesar $13 \%$.

Hasil analisis ragam menunjukkan bahwa pengaruh penambahan kombinasi gentamisin dengan minyak atsiri kulit jeruk manis sebagai bahan pengencer berpengaruh sangat nyata $(\mathrm{P}<0,01)$ terhadap spermatozoa hidup spermatozoa baik sebelum pembekuan maupun setelah pembekuan. Hasil uji lanjut menunjukkan bahwa spermatozoa hidup terbaik terdapat pada penambahan $1 \%$ yaitu $88 \%$ sebelum pembekuan dan $75 \%$ setelah pembekuan. 
Seluruh perlakuan memenuhi syarat untuk dilakukan Inseminasi Buatan. Badan standarisasi Nasional menetapkan kualitas semen sesudah proses pembekuan harus menunjukkan presentase spermatozoa hidup (viabilitas) minimal 40\% (Feradis, 2014). Penurunan kualitas spermatozoa setelah disebabkan karena spermatozoa mengalami cold shock (kejutan dingin) (Toelihere, 1993).

Spermatozoa yang tidak bergerak belum tentu mati sehingga tidak menyerap warna, sedangkan pada penafsiran dengan dasar bergerak dan tidak bergerak dianggap immotil. Pada spermatozoa yang hidup dan bergerak namun terdapat cacat pada dinding selnya, dapat menyerap warna dianggap mati, sedang penafsiran yang lain dianggap tidak mati (Partodihardjo, 1987).

Minyak atsiri jeruk manis mengandung limonene dan linalool bersifat toksik pada bakteri (Fisher \& Phillips, 2006). Selain itu juga mengandung flavonoid yang berfungsi sebagai antibakteri dan antioksidan (Dwijoseputro, 2005). Beconi et al. (1993) menyatakan bahwa pada semen dengan kualitas bagus penambahan antioksidan akan mempertahankan daya hidup sperma yang dibekukan tetapi tidak demikian dengan kualitas rendah karena peroksidasi tidak dapat diatasi dengan penambahan antioksidan. Nilai presentase spermatozoa hidup rendah salah satunya adalah karena pada bahan pengencer yang digunakan tidak terdapat antibakteri. Menurut Rizal \& Herdis (2008) salah satu syarat pada bahan pengencer semen adalah penambahan bahan yang mengandung antibakteri. Bakteri yang terkandung dalam semen beku dapat menurunkan kualitas semen, termasuk nilai presentase spermatozoa hidup spermatozoa (Toelihere, 1993).

Peroksidasi lipid akan menyebabkan kerusakan struktur dan terganggunya metabolisme spermatozoa yang berakibat spermatozoa mati. Antioksidan merupakan senyawa yang bersifat nucleophilic yang dapat memadamkan atau menekan reaksi bebas dan mampu untuk mengakhiri siklus reaksi. Antioksidan mempunyai pengaruh perlawanan yang tepat terhadap peroksidasi. Untuk penyimpanan spermatozoa sebaiknya dilakukan pada konsentrasi $\mathrm{O}_{2}$ yang rendah dan mengandung antioksidan pada pengencer. Hal ini dapat dilakukan dengan menggunakan kontainer yang tertutup sehingga dapat mengontrol lingkungan di sekitar spermatozoa (Hammerstedt, 1993).

\section{KESIMPULAN}

Hasil penelitian menunjukkan bahwa penambahan minyak atsiri jeruk manis pada bahan pengencer semen beku Sapi Simmental dapat meningkatkan persentase spermatozoa hidup dan layak digunakan untuk Inseminasi Buatan dengan penambahan terbaik sebanyak 1\%.

\section{DAFTAR PUSTAKA}

Beconi, M.T., Francia, C.R., Mora, N.G., \& Afranchino, M. A. (1993). Effect of natural antioksidant on frozen bovine semen preserpation. Therionology, 40, 841-851.

Dwidjoseputro, D. (2005). Dasar Dasar Mikrobiologi. Jakarta: Penerbit Djambatan.

Feradis. (2014). Bioteknologi Reproduksi pada Ternak. Bandung: Alfabeta.

Fisher, K. \& Phillips, C. A. (2006). The effect of lemon, orange and bergamot essential oils and their components on the survival of Campylobacter jejuni, Escherichia coli 0157, Listeria monocytogenes, Bacillus cereus and Staphylococcus aureus in vitro and food systems. J Appl Microbiol, 101(6), 1232-40.

Hammerstedt, R.H. (1993). Maintance of bioenergetic balance in sperm and prevention of lipid peroxidation: a review of the effect on design of storage preservation system. Reprod Fert Dev, $5,675-765$. 
Hasan, S., Andrabi, S.M.H., Munir, R., Jehangir, M., Shafique, P., Anzar, M., \& Ahmad, N. (2000). Effect of new antibiotic combination on post-thaw semen quality of buffalo and sahiwal bulls. $33^{r d}$ Annual Meet Soc Study Reprod, 62, 157.

Marisa, J. \& Sitepu, S. A. (2020). Beef cattle livestock business income analaysis in West Binjai District, Indonesia. Asian Journal of Advances in Agricultural Research, 13(1), 24-29.

Nattadiputra, S \& Munaf, S. (2009). Aminoglikosida dan Beberapa Antibiotika Khusus, Kumpulan Kuliah Farmakologi, 631. Jakarta: EGC.

Partodihardjo, S. (1987). Ilmu Reproduksi Hewan. Bogor: Fakultas Kedokteran Veteriner Jurusan Reproduksi Institut Pertanian Bogor.

Rizal, M. \& Herdis. (2008). Inseminasi Buatan pada Domba. Jakarta: Rineka Cipta, Jakarta.

Salmah. N. (2014). Motilitas, Persentase Hidup dan Abnormalitas Spermatozoa Semen Beku Sapi Bali Pada Pengencer Andromed dan Tris Kuning Telur. Makassar: Fakultas Peternakan Universitas Hasanudin.

Sitepu, S. A. \& Marisa, J. (2019). The effect of addition sweet orange essential oil and penicillin in tris yolk extender to simmental liquid semen against percentage motility, viability and abnormalities of spermatozoa. In: IOP Conference Series: Earth and Environmental Science, 287(1), 012007.

Toelihere, M. R. (1993). Fisiologi Reproduksi pada Ternak. Bogor: IPB Press.

Yuwanta, T. (2010). Telur dan Kualitas Telur. Yogyakarta: Gadjah Mada University Press. 